\title{
Angka Kuman Es Batu Produksi Rumah Tangga
}

\author{
Annisa Nur Yulianti, Ratih Dewi Dwiyanti, Wahdah Norsiah, Leka Lutpiatina
}

\author{
Jurusan Analis Kesehatan Poltekkes Kemenkes Banjarmasin \\ JI Mistar Cokrokusumo 4a Banjarbaru \\ e-mail: leka.zns@gmail.com
}

\begin{abstract}
Water is a human need, both for daily needs such as bathing, washing, cooking and drinking. Water is not only for drinking water, but can be made ice cubes that meet bacteriological requirements. The study aims to determine the results of TPC (Total Plate Count) on ice cubes produced by households in Kelurahan Sungai Besar. This research is a descriptive survey, the sample is examined using the TPC (Total Plate Count) method with dilutions of $10^{0}-10^{-4}$. Examination samples in the form of ice cubes were taken from the production house in Kelurahan Sungai Besar which amounted to 6. The results of the research from 24 ice cubes of household production in Sungai Besar Village were 2 samples that met the requirements and 22 samples did not meet the requirements. The conclusion of this study is that $80 \%$ of the samples do not meet the requirements of the Standar National Indonesia (SNI) 01-3553-2006. Further research suggestions by identifying the types of bacteria found in the ice cubes.
\end{abstract}

Keyword : germ number, ice cubes

Abstrak: Air adalah kebutuhan dasar manusia, baik untuk keperluan sehari-hari seperti mandi, cuci, masak, dan minum. Air tidak hanya untuk air minun saja, tetapi dapat dibuat es batu yang memenuhi syarat bakteriologis. Penelitian bertujuan untuk mengetahui hasil TPC (Total Plate Count) pada es batu produksi rumah tangga di Kelurahan Sungai Besar. Penelitian ini bersifat survei deskriptif, sampel diperiksa dengan menggunakan metode TPC (Total Plate Count) dengan pengenceran $10^{\circ}$ sampai $10^{-4}$. Sampel pemeriksaan berupa es batu yang diambil dari rumah produksi di Kelurahan Sungai Besar yang berjumlah 6 . Hasil penelitian dari 24 sampel es batu produksi rumah tangga di Kelurahan Sungai Besar adalah 2 sampel yang memenuhi syarat dan 22 sampel tidak memenuhi syarat. Kesimpulan dari penelitian ini adalah $80 \%$ sampel tidak memenuhi syarat Standar Nasional Indonesia (SNI) 01-3553-2006. Saran penelitian lebih lanjut dengan melakukan identifikasi terhadap jenis bakteri yang terdapat dalam es batu tersebut.

Kata Kunci: angka kuman, es batu

Copyright (C) 2018 Jurnal Skala Kesehatan. Politeknik Kesehatan Banjarmasin All rights reserved

Corresponding Author:

Annisa Nur Yulianti,

Jurusan Analis Kesehatan Poltekkes Kemenkes Banjarmasin

JIn H. Mistar Cokrokusumo No.4A Banjarbaru

Email : leka.zns@gmail.com 


\section{PENDAHULUAN}

Air merupakan bahan yang sangat penting bagi kehidupan manusia dan fungsinya tidak pernah dapat digantikan oleh senyawa lain, dalam keadaan kesulitan bahan pangan dan air, manusia akan bertahan hidup tanpa makan selama lebih dua bulan, tetapi tanpa air manusia akan meninggal dunia dalam waktu kurang dari seminggu (1).

Air adalah kebutuhan dasar manusia, baik untuk keperluan sehari-hari seperti mandi, cuci, masak dan minum. Air tidak hanya digunakan sebagai minum saja, tetapi juga dapat dipakai sebagai olahan. Salah satunya diolah menjadi es batu. Es batu adalah air yang dibekukan atau didinginkan sampai menjadi keras seperti batu tanpa campuran bahan lain.

Es batu sekarang ini sudah hampir menjadi kebutuhan utama. Baik keperluan pribadi ataupun pasar. Bagi individu, es batu banyak digunakan sebagai campuran minuman seperti: es dawet, es cendol, es jeruk, es kelapa, dan lain-lain, sedangkan bagi industri es batu digunakan sebagai pengawet ikan yang dikirim Pembekuan es batu melalui proses pendinginan air dibawah suhu $0^{\circ} \mathrm{C}$. Air yang digunakan dalam proses pembuatan es batu haruslah air yang bahan baku higienis dan sudah memenuhi standar sanitasi (2).

Timbulnya penyakit yang berkaitan dengan konsumsi es batu dapat dihubungkan antara lain dengan kurang diperhatikannya faktor kebersihan dan sanitasi dalam penanganan es batu. Hal tersebut menjadikan tingginya peluang kontaminasi mikrobiologis pada es batu (3). Menurut Standar Nasional Indonesia (SNI) 01-3553-2006, standar TPC untuk air minum dalam kemasan adalah maksimal 1,0 x $10^{2} \mathrm{koloni} / \mathrm{ml}$ (4).

Hasil penelitian Ariyani dan Anwar, (2006). Menunjukkan bahwa minuman dengan risiko tinggi kontaminasi mikroba di sekolah dasar (SD) Panaragan yang meliputi es doger, es campur, dan es kelapa, sebagian besar minuman ini mengandung santan dengan total mikroba $10^{8} \mathrm{koloni} /$ gram. Pada SD Empang yang meliputi es jeruk dan es kemasan dengan total mikroba $10^{6} \mathrm{koloni} / \mathrm{gram}$, dan di SD Papandayan adalah es doger, es sirsak, es kemasan dan, es teh dengan total mikroba $10^{7}$ koloni/gram. Kualitas mikrobiologi minuman yang dijual oleh pedagang kaki lima secara signifikan dipengaruhi oleh udara, tempat penyimpanan dan lingkungan (5).

Hasil penelitian Hadi, dkk (2014). Dari delapan sampel es batu Rumah Tangga menunjukan bahwa $88,9 \%$ belum memenuhi syarat kesehatan pada penjual minuman di pasar Lubuk Buaya Kota Padang yang memiliki nilai indeks MPN sekitar 9 sampai > 979 / $100 \mathrm{ml}$ sampel (2).

Hasil observasi yang telah dilakukan di wilayah Sungai Besar Banjarbaru terdapat sekitar 6 produksi rumah tangga pembuat es batu. Pengamatan sementara es batu tersebut masih menggunakan air yang berasal dari perusahaan daerah air minum (PDAM) tanpa melalui proses pendidihan, sehingga diduga air tersebut mengandung bakteri. Proses pembekuan tidak mematikan bakteri. Beberapa bakteri dapat bertahan hidup pada suhu yang rendah untuk jangka waktu yang relatif panjang. Bakteri ini dapat menyebabkan penyakit alat pencernaan (6). Penelitian ini bertujuan untuk mengetahui gambaran hasil TPC (Total Plate Count) dalam es batu produksi rumah tangga.

\section{BAHAN DAN METODE}

Metode yang digunakan dalam penelitian ini adalah jenis penelitian survei deskriptif, yaitu untuk melihat gambaran hasil TPC (Total Plate Count) dalam es batu produksi rumah tangga di Kelurahan Sungai Besar Kotamadya Banjarbaru Maret Tahun 
2017.

Sampel yang digunakan dalam penelitian ini adalah es batu produksi rumah tangga. Sebanyak 6 produksi rumah tangga, di ambil sebanyak 2 buah dan diambil lagi pada minggu berikutnya 2 buah es batu. Jumlah es batu sebanyak 24 buah. Cara pengambilan sampel dengan total sampel. Variabel penelitian adalah hasil TPC (Total Plate Count) dalam es batu produksi rumah tangga.

Es batu dicairkan secara aseptis, sampai mencair seluruhnya di lemari Biological Safety Cabinet (BSC). Pemeriksaan TPC dengan cara mengencerkan sampel $10^{0}-10^{-4}$, Dari masing-masing pengenceran dan kontrol ( $\mathrm{NaCl}$ steril) dipipet sebanyak $1 \mathrm{ml}$ dan dimasukkan kedalam cawan petri. Ditambah Nutrien Agar (Merck) masing-masing $20 \mathrm{ml}$, kemudian dihomogenkan. Setelah beku inkubasi pada suhu $370 \mathrm{C}$ selama $2 \times 24$ jam. Koloni yang tumbuh antara 30-300 dimasukkan perhitungan dengan rumus sebagai berikut :

Nilai TPC $(\mathrm{CFU} / \mathrm{ml})=\underline{(\Sigma \text { Koloni Kuman }- \text { Kontrol }) \times \text { pengenceran }}$

$$
\Sigma \text { Cawan Petri yang Dihitung }
$$

Data dari hasil pemeriksaan TPC (Total Plate Count) dirata-ratakan dan diprosentasikan. Kemudian dibandingkan dengan SNI 01-3553-2006 tidak melebihi 1,0x 10²Koloni/ml.

\section{HASIL DAN PEMBAHASAN}

Pemeriksaan TPC (Total Plate Count) pada es batu produksi rumah tangga di Sungai Besar maka didapatkan hasil tertera pada tabel 1 dan 2 dibawah ini :

Tabel 1 : Hasil Uji TPC (Total Plate Count) minggu pertama pada es batu produksi rumah tangga di Sungai Besar.

\begin{tabular}{|c|c|c|c|c|c|c|c|c|c|}
\hline \multirow[t]{2}{*}{ No } & \multirow{2}{*}{$\begin{array}{l}\text { Kode } \\
\text { Sampel }\end{array}$} & \multicolumn{5}{|c|}{ Pengenceran } & \multirow[t]{2}{*}{ Kontrol } & \multirow{2}{*}{$\begin{array}{l}\text { CFU } \\
/ \mathrm{ml}\end{array}$} & \multirow{2}{*}{$\begin{array}{l}\text { Rata- } \\
\text { rata }\end{array}$} \\
\hline & & $10^{0}$ & $10^{-1}$ & $10^{-2}$ & $10^{-3}$ & $10^{-4}$ & & & \\
\hline \multirow[t]{2}{*}{1} & A 1 & 49 & 30 & 1 & 0 & 0 & 0 & 174,5 & 985 \\
\hline & A 2 & 50 & 40 & 0 & 0 & 0 & 0 & 225 & \\
\hline \multirow[t]{2}{*}{2} & B 1 & 14 & 1 & 0 & 0 & 0 & 0 & 14 & 29,5 \\
\hline & B 2 & 45 & 15 & 0 & 0 & 0 & 0 & 45 & \\
\hline \multirow[t]{2}{*}{3} & C 1 & 100 & 88 & 15 & 0 & 0 & 0 & 490 & 345 \\
\hline & C 2 & 200 & 12 & 7 & 5 & 4 & 0 & 200 & \\
\hline \multirow[t]{2}{*}{4} & D 1 & 300 & 137 & 32 & 2 & 0 & 0 & 1623,5 & 8,187 \\
\hline & D 2 & 134 & 19 & 11 & 10 & 0 & 0 & 139 & \\
\hline \multirow[t]{2}{*}{5} & E 1 & 200 & 40 & 22 & 0 & 0 & 0 & 300 & 158,2 \\
\hline & E 2 & 17 & 14 & 13 & 0 & 0 & 0 & 17 & \\
\hline \multirow[t]{2}{*}{6} & F 1 & 126 & 31 & 4 & 3 & 0 & 0 & 217,5 & 4,021 \\
\hline & F 2 & 300 & 260 & 150 & 20 & 0 & 0 & 5867 & \\
\hline
\end{tabular}


Tabel 2 : Hasil Uji TPC (Total Plate Count) minggu kedua pada es batu produksi rumah tangga di Sungai Besar.

\begin{tabular}{lllccccccc}
\hline No & Kode & \multicolumn{9}{c}{ Pengenceran } & Kontr & CFU/ml & Rata- \\
\cline { 3 - 7 } & Sampel & $10^{0}$ & $10^{-1}$ & $10^{-2}$ & $10^{-3}$ & $10^{-4}$ & ol & & rata \\
\hline 1 & A 1 & 100 & 10 & 9 & 0 & 0 & 0 & 100 & 625 \\
& A 2 & 300 & 200 & 17 & 1 & 1 & 0 & 1150 & \\
2 & B 1 & 285 & 185 & 59 & 55 & 9 & 0 & 10758,7 & 565,07 \\
& & & & & & & & 5 & 5 \\
& B 2 & 300 & 280 & 250 & 189 & 0 & 0 & 54,275 & \\
3 & C 1 & 200 & 30 & 51 & 9 & 0 & 0 & 1866,67 & 166,16 \\
& C 2 & 100 & 87 & 34 & 1 & 0 & 0 & 1456,67 & 7 \\
4 & D 1 & 100 & 2 & 1 & 0 & 0 & 0 & 100 & 100 \\
& D 2 & 100 & 2 & 1 & 0 & 0 & 0 & 100 & \\
5 & E 1 & 78 & 60 & 1 & 0 & 0 & 0 & 339 & 269,5 \\
& E 2 & 200 & 11 & 4 & 0 & 0 & 0 & 200 & \\
6 & F 1 & 300 & 200 & 76 & 5 & 0 & 0 & 3300 & 1,750 \\
& F 2 & 200 & 5 & 4 & 0 & 0 & 0 & 200 & \\
\hline
\end{tabular}

\section{Karakteristik Responden}

Pendidikan responden di Kelurahan Sungai Besar $66 \%$ dengan tingkat pendidikan SMA. Untuk mengetahui tingkat pendidikan dapat dilihat pada tabel 3.

Tabel 3: Tingkat pendidikan Kelurahan Sungai Besar

\begin{tabular}{cccc}
\hline No & $\begin{array}{c}\text { Tingkat } \\
\text { Pendidikan }\end{array}$ & Jumlah & Persen (\%) \\
\hline 1. & SD & 1 & 17 \\
2. & SMP & 1 & 17 \\
3. & SMA & 4 & 66 \\
& Jumlah & 6 & 100 \\
\hline
\end{tabular}

Sumber air yang digunakan untuk pembuatan es batu menggunakan air Sumur. Untuk lebih jelas lihat tabel 4.

Tabel 4 : Distribusi cara pengolahan pembuatan es batu di Kelurahan Sungai Besar.

\begin{tabular}{llcc}
\hline No & Sumber air & Jumlah & Persen (\%) \\
\hline 1. & PDAM & 1 & 17 \\
2. & Sumur & 5 & 83 \\
3. & Sungai & 0 & 0 \\
& Jumlah & 6 & 100 \\
\hline
\end{tabular}

Sebagian besar pengolahan es batu di Kelurahan Sungai Besar tidak dimasak sebanyak $100 \%$. Untuk lebih jelas dilihat pada tabel 5. 
Tabel 5: Distribusi cara pengolahan pembuatan es batu di Kelurahan Sungai Besar.

\begin{tabular}{llcc}
\hline No & Cara pengolahan & Jumlah & Persen $(\%)$ \\
\hline 1. & Dimasak & 0 & 0 \\
2. & Tidak dimasak & 6 & 100 \\
& Jumlah & 6 & 100 \\
\hline
\end{tabular}

Penjualan es batu yang dilakukan responden secara diwarung dan dirumah. Untuk lebih jelas dapat dilihat pada tabel 6 .

Tabel 6 : Distribusi penjualan es batu di Kelurahan Sungai Besar.

\begin{tabular}{llcc}
\hline No & Penjual & Jumlah & Persen $(\%)$ \\
\hline 1. & Warung & 6 & 100 \\
2. & Rumah & 0 & 0 \\
& Jumlah & 6 & 100 \\
\hline
\end{tabular}

Responden menggunakan frezzer yaitu $100 \%$ untuk membuat es batu. Untuk lebih jelas lagi dapat dilihat pada tabel 7 .

Tabel 7 : Distribusi sumber air yang digunakan untuk pembuatan es batu di Kelurahan Sungai Besar.

\begin{tabular}{llcc}
\hline No & Lemari es & Jumlah & Persen (\%) \\
\hline 1 & Frezzer & 6 & 100 \\
2 & Kulkas rumah tangga & 0 & 0 \\
& Jumlah & 6 & 100 \\
\hline
\end{tabular}

Seluruh responden sudah menjaga hygiene dan sanitasi, salah satunya dengan mencuci tangan sebelum membuat es batu. Untuk lebih jelas dapat dilihat pada tabel 8.

Tabel 8 : Distribusi responden yang mencuci tangan sebelum membuat es batu di Kelurahan Sungai Besar.

\begin{tabular}{llcc}
\hline No & $\begin{array}{l}\text { Melaksanakan cuci } \\
\text { tangan }\end{array}$ & Jumlah & Persen (\%) \\
\hline 1 & Ya & 6 & 100 \\
2 & Tidak & 0 & 0 \\
& Jumlah & 6 & 100 \\
\hline
\end{tabular}

Seluruh responden sudah menggunakan alat-alat yang disediakan secara khusus untuk membuat es batu. Untuk lebih jelas dapat dilihat pada tabel 9.

Tabel 9. Penyimpanan alat-alat untuk membuat es batu di Kelurahan Sungai Besar.

\begin{tabular}{llll}
\hline No & $\begin{array}{c}\text { Penyimpanan alat-alat } \\
\text { untuk membuat es batu } \\
\text { secara khusus }\end{array}$ & Jumlah & Persen (\%) \\
\hline 1 & Ya & 60 & 100 \\
2 & Tidak & 0 & 0 \\
& Jumlah & 6 & 100 \\
\hline
\end{tabular}


Sebanyak $66 \%$ responden mampu membuat $>25$ bji es batu dalam sehari. Untuk lebih jelas dilihat pada tabel 10 .

Tabel 10. Banyaknya es batu yang dibuat responden dalam satu hari di Kelurahan Sungai besar.

\begin{tabular}{cccc}
\hline No & $\begin{array}{c}\text { Banyaknya es batu yang dibuat } \\
\text { responden dalam satu hari }\end{array}$ & Jumlah & Persen (\%) \\
\hline 1 & $<10$ & 0 & 0 \\
2 & $>10$ & 2 & 34 \\
3 & $>25$ & 4 & 66 \\
& Jumlah & 6 & 100 \\
\hline
\end{tabular}

Es Batu yang dibuat oleh responden $66 \%$ tidak langsung habis dalam satu hari. Untuk lebih jelas dapat dilihat pada tabel 11.

Tabel 11. Penjualan es batu dalam satu hari di Kelurahan Sungai Besar.

\begin{tabular}{llcc}
\hline No & $\begin{array}{c}\text { Dalam satu hari es batu } \\
\text { Yang dibuat langsung habis }\end{array}$ & $\begin{array}{c}\text { Jumlah } \\
\text { Yarsen } \\
(\%)\end{array}$ \\
\hline 1 & Ya & 2 & 34 \\
2 & Tidak & 4 & 66 \\
& Jumlah & 6 & 100 \\
\hline
\end{tabular}

Berdasarkan hasil penelitian pemeriksaan TPC (Total Plate Count) pada minggu pertama dari 12 sampel yang diperiksa yang memenuh standar SNI adalah sampel B1, B2, dan E2 dan minggu kedua dari 12 sampel yang memenuhi syarat standar SNI adalah A1, D1, dan D2. Dari 6 sampel yang memenuhi syarat SNI, ditinjau dari tingkat pendidikan 3 sampel dari produsen berpendidikan SMA dan 3 sampel berpendidikan SD dan SMP. Sumber air yang digunakan sebagai bahan baku, 1 sampel sumber air dari PDAM dan 5 sampel dari air sumur, berdasarkan cara pengolahan semua sampel baik yang memenuhi syarat SNI maupun tidak memenuhi syarat SNI sampel menggunakan air yang tidak dimasak.

Air yang digunakan untuk membuat es batu seharusnya dimasak terlebih dahulu untuk mematikan bakteri yang terdapat didalam air dengan mendidihkan sekurangkurangnya 5 menit, lama waktu membiarkan air mendidih di kompor adalah selama 20 menit agar semua bakteri patogen yang hidup mati. Air PDAM hasil menunjukan minggu pertama positif dikarena air yang digunakan keruh dan kotor saat mencair sedangkan pada minggu kedua negatif, sedangkan air sumur (75\%) dinyatakan hasil positif dan (25\%) negatif.

Bahan baku yang dipakai dalam pembuatan es batu $100 \%$ tidak dimasak dan sumbernya dari air sumur dan air PDAM. Jika air yang digunakan tercemar oleh bakteri, maka es batu yang dihasilkan dapat membahayakan kesehatan manusia yang mengkonsumsinya. Hasil penelitian menunjukan bahwa air sumur melebihi standar SNI, sedangkan air PDAM pada minggu pertama melebihi standar SNI disebabkan karena warna airnya keruh dan kotor pada minggu kedua hasil menunjukan hasil memenuhi standar SNI. 
Menurut Slamet S. (2004) jika air tercemar oleh bakteri maka dapat menyebabkan berbagai macam penyakit saluran pencernaan, misalnya kolera, disentri, dan diare. Air yang digunakan untuk membuat es batu seharusnya dimasak terlebih dahulu untuk mematikan bakteri-bakteri yang ada dalam air sehingga aman untuk dikonsumsi (7).

Peralatan yang digunakan dari seluruh responden untuk membuat es batu seperti gayung dan ember sudah disediakan secara khusus, tetapi peralatan tersebut dianggap kurang bersih karena mencucinya masih menggunakan air sumur dan PDAM. Menurut Pelezar (1988) pencemaran makanan dan minuman oleh bakteri lewat alat-alat dapat dikurangi bila pencucian alat tersebut dilakukan dengan sanitasi yang baik (8).

Higiene dan sanitasi pembuatan es batu juga sangat mempengaruhi. Dari hasil pengamatan, responden tersebut sebanyak $100 \%$ sudah mencuci tangan sebelum membuat es batu. Hal ini menunjukan bahwa kesadaran masyarakat terhadap hygiene dan sanitasi sudah cukup baik. Menurut Pelezar (1988) kebersihan perorangan sangat penting dalam pengendalian keracuanan makanan dan minuman oleh bakteri yang masuk ketubuh melalui tinja-mulut.

Menurut Azul Anwar (1990) salah satu upaya untuk menghindari pencemaran atau kontaminasi oleh bakteri pada air yang digunakan untuk pembuatan es batu antara lain yaitu : meninggkatkan hygiene atau kebersihan perorangan, menggunakan peralatan yang bersih, menggunakan air yang direbus sampai mendidih sehingga dapat mematikan bakteri penyebab penyakit yang ada di dalamnya, menggunakan tempat penampungan air yang bersih dan tertutup rapat, menciptakan lingkungan pengolahan yang bersih (9).

\section{KESIMPULAN}

Nilai TPC (Total Plate Count) minggu pertama : A: $985 \mathrm{CFU} / \mathrm{mL}$; B: $29,5 \mathrm{CFU} / \mathrm{mL}$ ; C: $345 \mathrm{CFU} / \mathrm{mL}$; D: 8,187 CFU/mL ; E: 158,2 CFU/mL ; F: 4,021 CFU/mL dan minggu kedua : A: $625 \mathrm{CFU} / \mathrm{mL}$; B: 565,075 CFU/mL ; C: $166,167 \mathrm{CFU} / \mathrm{mL}$; D: $100 \mathrm{CFU} / \mathrm{mL}$; E: $269,5 \mathrm{CFU} / \mathrm{mL} ; \mathrm{F}: 1750 \mathrm{CFU} / \mathrm{mL}$. Hasil pemeriksaan TPC (Total Plate Count) di dapatkan hasil dari 24 sampel 2 sampel memenuhi syarat Standar SNI dan 22 sampel yang tidak memenuhi syarat Standar SNI.

\section{DAFTAR PUSTAKA}

(1) Winarno, F.G, Kimia Pangan dan Gizi. PT Gramedia Pustaka Utama, 2004

(2) Hadi Basri, dkk, "Uji Bakteriologi Es Batu Rumah Tangga Yang Digunakan Penjual minuman di Pasar Lubuk Buaya Kota Padang", Jurnal Kesehatan Andalas. Vol. 3 No. 2, 2014

(3) Purawijaya, Tatang, Keracunan Makanan di Indonesia. Materi Pelatihan Singkat Keamanan Pangan, Standar dan Peraturan Pangan, PAU Pangan dan Gizi, 1992

(4) Ariyani dwi dan Anwar fasil. "Mutu Mikrobiologi Minuman Jajanan Di Sekolah Dasar Wilayah Bogor Tengah" Jurnal Gizi dan Pangan. Vol. 1 No.1, 2006

(5) Badan Standarisasi Nasional 2006. SNI 01- 3553-2006. Air Minum Dalam Kemasan, Standar Nasional Indonesia

(6) Volk, A Weasly dan Wheeler M. F, Mikrobiologi Dasar. Edisi Revisi. Jilid 2 Penerbit Erlangga. Jakarta, 1992

(7) Slamet Juli Soemirat, Kesehatan Lingkungan, Gajah Mada University Press Bandung 2004. 
(8) Pelezar, M, J. dan E. C. S. Chan, Dasar-Dasar Mikrobiologi. Jilid 2. Universitas Indonesia Press. Jakarta, 1988

(9) Azwar, Azrul, Pengantar Ilmu Kesehatan Lingkungan . Mutiara Sumber Widya, Jakarta, 1990 